\title{
Research on Mixed Ownership Economy Development in Hubei Province
}

\author{
Li Xiuping
}

Wuhan Donghu University, Wuhan, Hubei, China, 430077

\begin{abstract}
With the focus on equity diversified reform, the mixed ownership economy in Hubei Province has achieved certain results in promoting the innovation of property right system. But, it also still faces some constraints and difficulties. To accelerate the development of the mixed ownership economy in Hubei Province, we need to deepen the reform, clear the different market participants which can hold industries, improve the legal environment and occupation manager system, perfect the property market and conduct effective supervision of the economy of mixed ownership of assets.
\end{abstract}

KEYWORDS: Mixed Ownership Economy; Hubei Province

\section{INTRODUCTION}

A: Cultivate a Group of Mixed Ownership Enterprises by Decoupling and Reforming

In order to promote the disadvantages of state-owned enterprises withdraw from the market and improve the quality and efficiency of state-owned capital operation as a whole, Hubei province state-owned enterprises increased the speed of withdrawalfrom general competition field. The government of Hubei Province, "a group through the decentralization of local, transferred to a group of a group, authorization, restructuring, a number of centralized custody group, the lifting link it a group of" other "a group of six" approach, the completion of 262 Hubei provincial authorities enterprises from the restructuring task, involving the assets of about 200 billion Yuan, a total of the resettlement staff 156,500 people. At present, the Hubei provincial state-owned assets for business operation have been basically achieved full coverage of supervision. The first is pushing forward the reform of company system. The second is to accelerate the development of small and medium-sized state-owned enterprises to withdraw. The third is to dispose of bad assets of state owned enterprises.

B: Develop a Group of Mixed Ownership Enterprises by IntroducingCapital

Through the introduction of large central enterprises, the advantages of private enterprises and well-known enterprises implement strategic cooperation to realize the enterprises under all forms of ownership in the system, resource advantage of grafting, learn from each other.We make the scale of the enterprise bigger and the strength of business stronger. The first is the cooperation with central enterprises. The second is the recombination of state-owned enterprises, private enterprises, foreign cooperative. The third is to promote the listing and financing.

C: Enliven a Group of Mixed Ownership Enterprises by Employee Stock Ownership

The management team management ability of the small and medium-sized enterprise stronger competition, has certain development potential, encourage management and employee stock ownership, state-owned capital choice relative holding, shares. Hubei seed group, the provincial Medicines Co before restructuring 
are old state-owned enterprise assets scale is small, poor profitability, in order to fully mobilize the enthusiasm of the staff and workers management and operation, the two enterprises open listing the introduction of private capital in the property rights trading market, and implementation of management and employee stock ownership, profits doubled. Sanhuan group encouraged subordinate enterprise management, employee stock ownership, at the same time, according to a certain proportion of state-owned stock dividends distribution, form a community of interests of capital owners and workers, promote the enterprise rapid development.

D: Strong a Group of Mixed Ownership Enterprises by Integration andRestructuring

The Hubei government at all levels to accelerate the restructuring of state-owned enterprises, to promote the state-owned capital to the advantage of enterprises, the advantage of products, advantage industry concentration, and further optimize the layout structure of the state-owned economy, the state-owned economy to further strengthen the overall competitiveness. The first is to optimize the industrial layout.The second is to highlight the main industry development. The third is to strong enterprise groups.

\section{Difficulties of Mixed Ownership Economy Development in Hubei Province}

\section{A: Many Restricted Factors of Non-public Economy}

At present, Hubei Province, the added value of non-public economy has accounted for $55 \%$ share of GDP, but the structure is not balanced (including industrial and regional imbalance), vitality is not strong, lack of power, to the family business, family business oriented management system of private enterprise to the modern enterprise system transition of clear property rights is restricted by the policy environment; the market main body, also has the rights and interests of inequality, inequality of opportunity, not equality rules, not only the field of investment limited, the lack of private capital and the discourse right of state-owned enterprise capital, it is difficult to effectively protect the legitimate rights and interests, private enterprise investor concerns more. In the discussion of research, many private entrepreneurs said, for the mixed ownership reform do not want to participate, but dare not to participate in the. The questionnaire also reflected that nearly $80 \%$ of people think that the development of the non-public sector of the economy of mixed ownership economy in market access on a hidden barriers, legal protection of property right definition and flow is not perfect.

B: Low Administration Level of State-owned Economy

By the of April of 2014, a total of local state-owned enterprises 327 in Hubei Province has total assets of more than 140 billion Yuan, net assets of nearly 50 billion Yuan, 30\% more than last year. Hubei Province invested enterprise asset size increased from 40 billion Yuan in 2003 to now 400 billion Yuan, an increase of 10 times, several Platform Co, net assets have been exceeded 100 billion Yuan, total financing of more than 200 billion Yuan, stimulate social investment more than 800billionYuan. At present, Hubei Province invested enterprise assets scale is only the central fourth, twenty-first places nationwide, the average size of assets of enterprises is only 1 billion, less than the central enterprises 1/20. Thirty-three province invested enterprises, do business only 3 homes, six governments Platform, government seven service companies. Overall, the state-owned enterprises in Hubei 
existing characteristics of small, scattered, weak, capital operation level is not high, the total assets in the national rankings is not high. The equity structure has not yet formed, the modern enterprise system has not been established, a few enterprises has not done the transformation to company norms, individual city states even last reform tasks are not completed. Some governments departments are still in the direct management of the enterprise, which will establish a new state-owned enterprise and authorize other functional departments perform the contributor's duties.

C: Perception Gap between State-owned Enterprises and Private Enterprises

Although the state-owned enterprises and private enterprises have expressed mixed with enthusiasm, but there are many gaps in understanding of it. The key dispute is the right of holding. From the view of many state-owned enterprises, state-owned enterprise managers for bigger and stronger consideration, in the introduction of social capital often requires absolute holdings, some in the industry dominant position of the state-owned enterprise managers are being "fertilizer outsiders do not flow fields" idea, not who were a cup of a thick soup; some state-owned enterprise managers worry about quality assets to carry out mixed, the remaining income generating ability weak assets and a large number of surplus workers is difficult to maintain. Private enterprises from the point of view, some of the strength of private enterprise owners being not let holdings than mixed thinking; there are a lot of private enterprise owners worry that after mixing, no right to speak, the legitimate rights and interests are not guaranteed; many private capital and state-owned capital is mainly to mix to profit, if unprofitable or limited profit, is reluctant to mixed. Look on the whole, the central enterprises a huge amount of assets, private capital to the mixture, the shareholding ratio of individual enterprises will be very limited, even the fusion of parts of the capital, sometimes also need to invest huge amounts of capital, such as the introduction of Sinopec start social and private capital reorganization of the oil sales, the preliminary results of the assessment is, Sinopec oil sales plate assets amounted to about 340 billion. If calculated in accordance with $30 \%$, the individual private enterprises such as to equity and pay 100 billion Yuan of funds, this is the individual private enterprises unbearable. At the same time, the state-owned enterprises and private enterprises have many differences in the management idea, system, mechanism, marketing, financial accounting and corporate culture.

\section{Suggestions of Mixed Ownership Economy Development in Hubei Province}

\section{A: Perfect Legal Environment.}

All major reforms will on the basis of laws. Promoting the mixed ownership reform needs the suitable legal and policy support. First, the mixed ownership reform should be carried out in the framework of company law. Company capital structure is diversified.Capital formation is mainly form of organization socialization and marketization of the capital operation. Provide a diversified capital organization form of modern enterprise system, company law, made a series of arrangements. Provisions concerning the company organization form and behavior of company law, provides the system safeguard for the mixed develop national capital, the equity ownership and other non-public ownership. If you want to make the implementation of mixed ownership results, you need to really in accordance with the requirements of modern 
enterprise system, the provisions of the company law to do, talk to equity, not on the level of identity nature. The second is to carry out the basic principles of the company law, the company law of our country stipulates the basic principles of no single set of chapters, but in practice, the basic principles of the company law should include the principle of balance of interests, the principle of separation of powers, the principle of autonomy, the principle of equality of shareholders, these principles such as effective implementation, you can ensure that the state-owned capital, non-public capital, play their proper role in the mixing process of mutual respect, harmonious coexistence, common benefits, risks. The three is to improve the "company law" and other laws and regulations system. The mixed ownership economy requires providing a more efficient system security, system framework and system resources of the requirements provided by the company law to solve the problems met in the reform.However,

\section{B: Improve DevelopmentEnvironment.}

To speed up the development of the non-public sectors of the economy and develop the public sector of the economy in the equally important strategic position, we realize the synchronized planning, deployment, synchronous inspection, appraisal synchronization. Formulated to encourage support and guide the development of the mixed ownership economy of the special policy, establish and improve various ownership economy "rights of equality, equality of opportunity, equal rules" of the development environment, to further promote the withdrawal of state-owned capital from the general competitive domain and does not have the competitive advantage in the industry, breaking the "glass door", "spring door" and the "revolving door". As soon as possible to publish to the society, state-owned enterprises need to adopt a wholly owned absolute holding and the relative holding industries and fields to encourage non ownership enterprises mixed public capital prohibits holding development industry.

\section{C: One Enterprise, One Policy}

We should continue to deepen the state-owned and state-owned enterprise property right system reform, as soon as possible to develop regulations to deepen the reform of state-owned enterprises or decided, to seek multiple forms for realizing public ownership system, speeding up the enterprise shareholding system reform and the establishment of modern enterprise system process, promoting the pluralism of investment subject, the formation of the mixed ownership economy property right structure. To distinguish between a mixtures of different enterprise ownership reform, as far as possible to the classification guidance of one enterprise, one policy. On the basic, public welfare, strategic industry enterprises, or keep the state owned, or in keeping with state-owned absolute holding, encourage other economy component shares, the formation of mixed control by the state-owned capital ownership economy; focus on the adjustment of state-owned economy field, with a certain scale and strong competitiveness of leading enterprises, change enterprise ownership structure, actively encourage foreign capital, private capital and the operator shares, transition from state-owned to relative holding, equity participation, to speed up the diversification of state-owned enterprise property right main body and to the development of the mixed ownership economy step. We can realize the state-owned capital withdraw by adopting centralized property right transfer, reducing of operator and the employee stock ownership of state-owned 
shares.

\section{D: Consummate Property Market}

Perfect mechanism and function of property rights trading market and strengthen the construction of the property right transaction information network to improve the system and network level, strengthen the property right transaction of professional talent team construction. We should improve the property right transaction specification level, reduce the transaction cost of property, to improve the capital allocation efficiency; speed up the establishment and improvement of laws and regulations related to the property rights trading market, perfect the supervision of property right system, including improving property exchange industry management, develop property rights trading rules, regulating property rights transaction procedures, the price formation mechanism of evaluation reasonable and fair, promoting property market standardization development; strict implementation of property rights trading in the market system, improve the degree of market operation of transaction of property right, to encourage non-public economic property into the transaction, promote property competition, activate the property market.The property market has become all kinds of market subjects and orderly competition, capital flow, asset restructuring, expansion and development platform.

\section{E: Supervise Assets Effectively}

The government should speed up the introduction of laws and regulations to encourage the development of mixed ownership. Perfect the policy supporting system. It also should develop the mixed ownership economy development to adapt to the new management methods of state-owned assets. For the mixed ownership economy has dual nature "is not only private", must be in accordance with the requirements of normative market economy audit procedures and content. The state-owned capital supervision mechanism to adapt to "the new change of mixed property rights" brought by regulation, good capital and sent by the directors of state-owned assets management to standardize the mixed ownership economy activities in the property as the link of capital cooperation, business cooperation and industrial cooperation behavior. F: Develop Systems of Occupation Managers

The first is to explore the market selection system. Promote the state-owned enterprisesremoval of abuse of administration to play a good role of entrepreneurs. The establishment of selection, appraisal, reward and punishment is good for enterprise management. The second is the implementation of the hierarchical management system. According to the rights, obligations and responsibilities of unity, the management of assets and managing people, purser combined requirements, established to meet the requirements of modern enterprise system, hierarchical classification management system. The implementation of hierarchical management, business management relation determined according to property right, constructing the contributor to appoint directors, board of supervisors, the board of directors to hire managers and directors, supervisors to contributive person responsible, managers will be responsible to the board of directors entrust agent system. The third is to improve the incentive and restraint mechanism. Gradually establish a short-term incentive and long-term incentive to complement each other, closely combined with strong motivation and hard constraints, salary distribution system of income linked to performance can fully reflect the enterprise leaders' contribution. The progressive realization of market selection operators 
implements market-oriented salary. According to the property right structure, company governance, different enterprise development stage and the degree of competition situation, the choice suits the actual business of long-term incentives, long-term promotion of management behavior. In addition, we should manage the relationship between the incentives of leadership and the income of employees.

\section{Conclusion}

There are a lot of places that do not suit with the reform of China's company law and other laws and regulations. We should improve laws and regulations in this regard to create a unified rule of law environment to promote the fair and efficient hybrid. Suggestions for state-owned capital to keep owned or holding the status of industries and fields defined in seven aspects: the first is the lifeblood of national economy relationship between natural monopoly fields; the second is an important public service facilities between social and economic development; the third is the natural resources between ecological security; the fourth is the defense industry and other special industry related to national security; the fifth is the relationship between national innovation ability important forward-looking strategic industry; the sixth is the policy business strong; the seventh is the state capital investment or state-owned capital operating. The establishment of property rights trading self-examination, checks, review system, conducts a special inspection approach transactions each year deal with state-owned. The establishment of property rights trading violation report system and accountability measures prevent mixing loss all assets system enterprises.

\section{ACKNOWLEDGEMENT}

Project Name: Study on Promoting Financial Support in New Urbanization in Hubei,ProjectNumber: 14G453

\section{REFERENCE:}

[1] Li Zhengtu. Actively DevelopMixed Ownership Economy: Strategic conception and Top Design. [J]. Economist. 2014(11)

[2] Tong Youhao. Five Problems should be Paid Attention to when Developing Mixed Ownership Economy [J].Academic Journal of Zhongzhou, 2014(07)

[3] Qian Kai. Summary of Viewpoints of how to Develop Mixed Ownership Economy.[J].Review of Economic Research, 2014(48) 